\title{
Finding inflammatory bowel disease genes will not lead to a cure
}

\author{
John K Marshall MD MSc FRCPC
}

$\mathrm{T}_{\mathrm{i} \text { he }}^{\mathrm{h}}$ he contribution of genetic factors to the pathogenesis of inflammatory bowel disease (IBD) is limited. The concordance between monozygotic twins is only $5 \%$ to $14 \%$ for ulcerative colitis, which suggests that environmental factors play a major role in the pathogenesis of the disease. On the other hand, for Crohn's disease (CD), the concordance may be as high as $50 \%(1,2)$. However, this overestimates genetic contribution because twins not only share genes but also a common childhood environment. Indeed, significant clustering among siblings with IBD suggests that birth order influences sibling phenotype and that the early environment is important (3).

The identification of the nucleotide oligomerization domain 2/caspase recruitment domain 15 (NOD2/CARD15) gene marked a major advance in our understanding of mechanisms underlying CD (4,5). However, the association between NOD2/CARD15 and CD phenotype is far from straightforward. In one published knock-out model (6), NOD2 mutation impaired mucosal immune response and increased susceptibility to infection. Conversely, a knock-in model that introduced a NOD2 mutation similar to the human variant, increased nuclear factor-kappa B activation and enhanced mucosal inflammatory responses to bacterial peptidoglycan in experimental colitis (7). However, no matter what its effect, the NOD2/CARD15 allele is carried by less than $50 \%$ of patients with CD and up to $20 \%$ healthy North Americans and Europeans (8). Hence, it is neither necessary nor sufficient to cause the disorder.

Temporal trends in epidemiology provide the most striking and compelling evidence of environmental influence on the pathogenesis of CD. CD was a relatively rare disorder over 100 years ago, but its incidence rose abruptly and dramatically in the middle third of the 20th century, and may now have reached a plateau (9). Such abrupt changes in epidemiology can only result from changes in the environment, which suggest that the role played by genetic factors is modest and largely permissive. Similarly, ethnic differences in the incidence of $\mathrm{CD}$ do not appear to reflect genetic predisposition and are lost with migration and/or changes in lifestyle $(10,11)$. Despite their ancestry, children of migrants assume the CD incidence of their new environment.

$\mathrm{CD}$ appears to be strongly associated with domestic hygiene, urbanization, affluence and westernization. Geographical trends suggest that $\mathrm{CD}$ is more common in northern climates, but this gradient is often confounded by socioeconomic status (9). CD has also been attributed to the altered gut immune response that results from reduced helminth exposure and colonization (12). Observed behaviours that influence the incidence of CD include smoking, use of oral contraceptives, high sugar and high fat diets, breastfeeding and use of toothpastes $(9,13)$. Conversely, appendectomy and smoking protect against ulcerative colitis (9).

Early childhood exposures may be the most important determinants of future CD. Associations between the birth month and the incidence of CD suggest that changes in climate or seasonal pathogens may be important contributing factors $(14,15)$. The major paradigm underlying proposed childhood risk factors is the so-called hygiene hypothesis, that associates $\mathrm{CD}$ with improved domestic cleanliness and reduced early antigen exposure $(16,17)$. Although early studies (18-20) were confounded by recall bias, acute childhood gastroenteritis (perhaps in the context of limited prior antigen exposure) appears to increase the risk of $\mathrm{CD}$; the incidence of $\mathrm{CD}$ is inversely associated with infant mortality $(11,21)$. Access to hot water and use of separate bathrooms have all been identified as risk factors $(16,17)$. A particularly intriguing hypothesis links CD to the advent of refrigeration and increased exposure to psychrotrophic microorganisms (22).

The most intimate interaction between humans and their environment is the juxtaposition of intestinal mucosa and gut luminal contents. Overwhelming evidence suggest that gut flora play a pivotal role in inducing and maintaining the inflammation of CD. Colitis in the murine interleukin-10 knock-out model requires gut flora, and can be attenuated by introducing specific probiotics or antibiotic treatment (23-26). Despite several compelling hypotheses, efforts to link specific pathogens to $\mathrm{CD}$ have not been successful. However, human CD may be associated with shifts in mucosal flora (27) and its course may be altered by antibiotic treatment (28). The use of probiotics for the treatment of $\mathrm{CD}$ is now a focus of intense clinical research.

In summary, IBD is a complex, polygenic disorder with incomplete genetic penetrance and poor genotype-phenotype correlation. Ultimately, the genetic contribution to the pathogenesis of IBD may be largely permissive. There is overwhelming evidence that environmental exposure drives disease expression and natural history. Indeed, there has been an abrupt and dramatic change in the epidemiology of CD over the past 100 years that can only reflect shifts in behaviour, lifestyle and environment. Only a better understanding of early environmental triggers will allow us to prevent and cure IBD in the future. Genetics may tell us where to look for a cure, but it is environmental research that will tell us what to do. 


\section{REFERENCES}

1. Tysk C, Lindberg E, Jarnerot G, Floderus-Myrhed B. Ulcerative colitis and Crohn's disease in an unselected population of monozygotic and dizygotic twins. A study of heritability and the influence of smoking. Gut 1988;29:990-6.

2. Ornholm M, Binder V, Sorensen TI, Rasmussen LP, Kyvik KO. Concordance of inflammatory bowel disease among Danish twins. Results of a nationwide study. Scand J Gastroenterol 2000;35:1075-81.

3. Hugot JP, Cezard JP, Colombel JF, et al; GETAID. Clustering of Crohn's disease within affected sibships. Eur J Hum Genet 2003;11:179-84.

4. Hugot JP, Chamaillard M, Zouali H, et al. Association of NOD2 leucine-rich repeat variants with susceptibility to Crohn's disease. Nature 2001;411:599-603.

5. Ogura Y, Bonen DK, Inohara N, et al. A frameshift mutation in NOD2 associated with susceptibility to Crohn's disease. Nature 2001;411:603-6

6. Kobayashi KS, Chamaillard M, Ogura Y, et al. Nod2-dependent regulation of innate and adaptive immunity in the intestinal tract. Science 2005;307:731-4.

7. Maeda S, Hsu LC, Liu H, et al. Nod2 mutation in Crohn's disease potentiates NF-kappaB activity and IL-1beta processing. Science 2005;307:734-8. (Erratum in 2005;308:633).

8. Newman B, Siminovitch KA. Recent advances in the genetics of inflammatory bowel disease. Curr Opin Gastroenterol 2005;21:401-7.

9. Loftus EV Jr. Clinical epidemiology of inflammatory bowel disease: Incidence, prevalence, and environmental influences. Gastroenterology 2004;126:1504-17.

10. Montgomery SM, Morris DL, Pounder RE, Wakefield AJ Asian ethnic origin and the risk of inflammatory bowel disease. Eur J Gastroenterol Hepatol 1999;11:543-6.

11. Wright JP, Froggatt J, O'Keefe EA, et al. The epidemiology of inflammatory bowel disease in Cape Town 1980-1984. S Afr Med J 1986;70:10-5.

12. Weinstock JV, Summers R, Elliott DE. Helminths and harmony. Gut 2004;53:7-9.

13. Korzenik JR. Past and current theories of etiology of IBD: Toothpaste, worms, and refigerators. J Clin Gastroenterol 2005;39:S59-65.

14. Van Ranst M, Joossens M, Joossens S, et al. Crohn's disease and month of birth. Inflamm Bowel Dis 2005;11:597-9.
15. Chowers Y, Odes S, Bujanover Y, Eliakim R, Bar Meir S, Avidan B. The month of birth is linked to the risk of Crohn's disease in the Israeli population. Am J Gastroenterol 2004;99:1974-6.

16. Gent AE, Hellier MD, Grace RH, Swarbrick ET, Coggon D. Inflammatory bowel disease and domestic hygiene in infancy. Lancet 1994;343:766-7.

17. Duggan AE, Usmani I, Neal KR, Logan RF. Appendicectomy, childhood hygiene, Helicobacter pylori status, and risk of inflammatory bowel disease: A case-control study. Gut 1998;43:494-8.

18. Whorwell PJ, Holdstock G, Whorwell GM, Wright R. Bottle feeding, early gastroenteritis, and inflammatory bowel disease. Br Med J 1979;1:382.

19. Ekbom A, Adami HO, Helmick CG, Jonzon A, Zack MM. Perinatal risk factors for inflammatory bowel disease: A case-control study. Am J Epidemiol 1990;132:1111-9.

20. Koletzko S, Sherman P, Corey M, Griffiths A, Smith C. Role of infant feeding practices in development of Crohn's disease in childhood. BMJ 1989;298:1617-8.

21. Montgomery SM, Pounder RE, Wakefield AJ. Infant mortality and the incidence of inflammatory bowel disease. Lancet 1997;349:472-3.

22. Hugot JP, Alberti C, Berrebi D, Bingen E, Cezard JP. Crohn's disease: The cold-chain hypothesis. Lancet 2003;362:2012-5.

23. Vandenbroucke K, Hans W, Van Huysse J, et al. Active delivery of trefoil factors by genetically modified Lactococcus lactis prevents and heals acute colitis in mice. Gastroenterology 2004;127:502-13.

24. McCarthy J, O'Mahony L, O'Callaghan L, et al. Double blind, placebo controlled trial of two probiotic strains in interleukin 10 knockout mice and mechanistic link with cytokine balance. Gut 2003;52:975-80

25. Steidler L, Hans W, Schotte L, et al. Treatment of murine colitis by Lactococcus lactis secreting interleukin-10. Science 2000;289:1352-5.

26. Madsen KL, Doyle JS, Tavernini MM, Jewell LD, Rennie RP, Fedorak RN. Antibiotic therapy attenuates colitis in interleukin 10 gene-deficient mice. Gastroenterology 2000;118:1094-105.

27. Kleessen B, Kroesen AJ, Buhr HJ, Blaut M. Mucosal and invading bacteria in patients with inflammatory bowel disease compared with controls. Scand J Gastroenterol 2002;37:1034-41.

28. Steinhart AH, Feagan BG, Wong CJ, et al. Combined budesonide and antibiotic therapy for active Crohn's disease: A randomized controlled trial. Gastroenterology 2002;123:33-40 


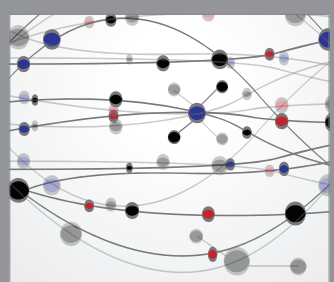

The Scientific World Journal
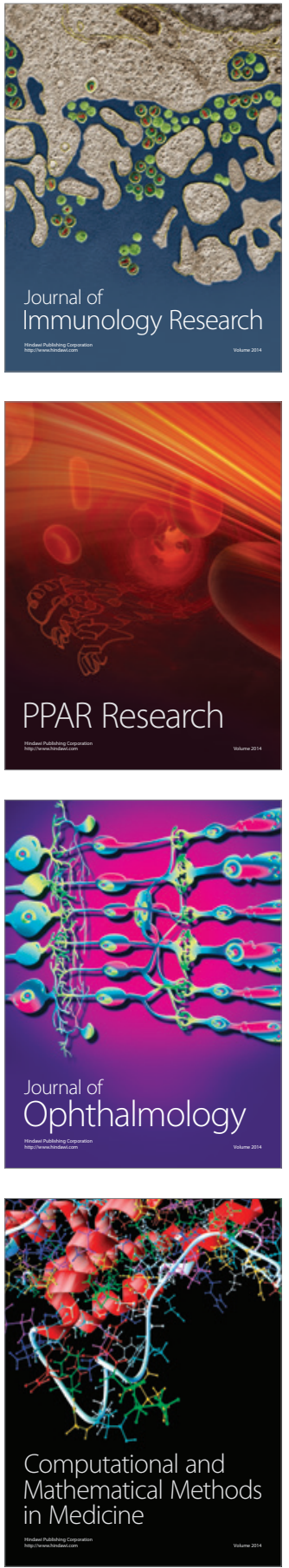

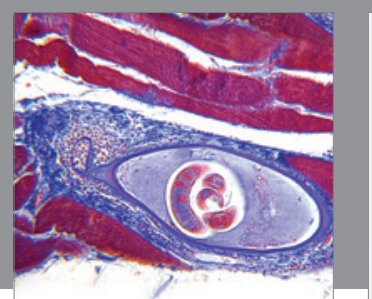

Gastroenterology Research and Practice

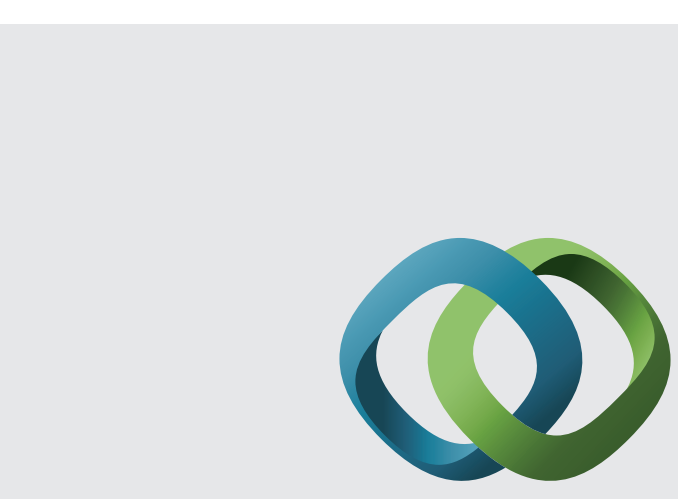

\section{Hindawi}

Submit your manuscripts at

http://www.hindawi.com
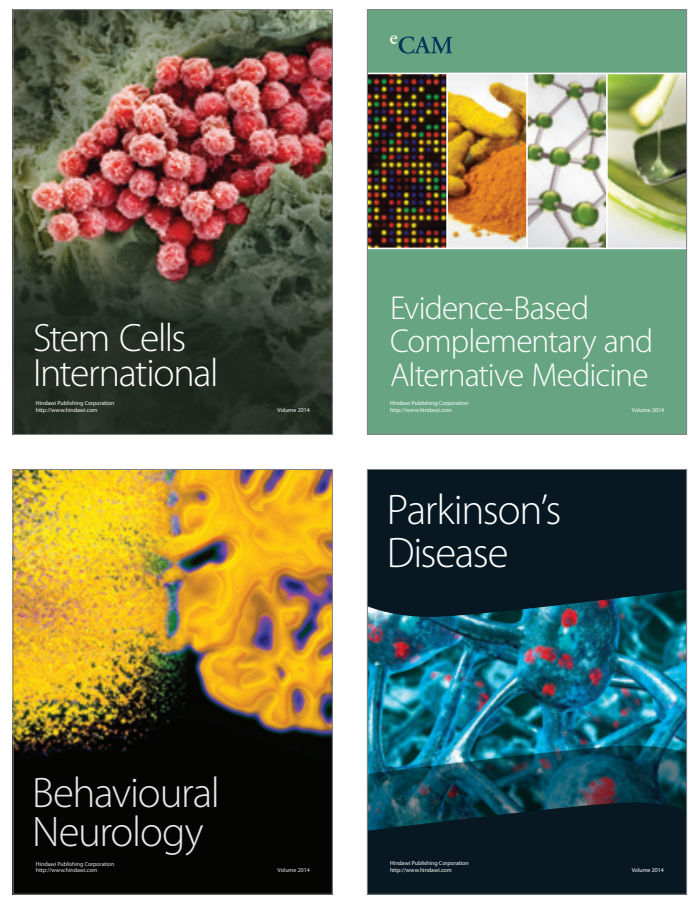
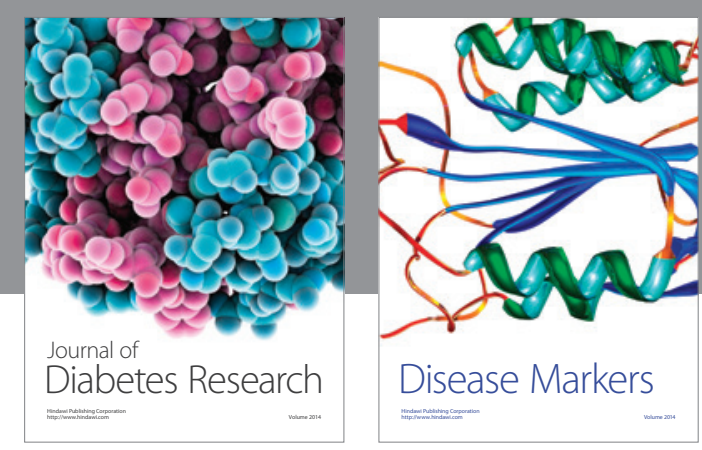

Disease Markers
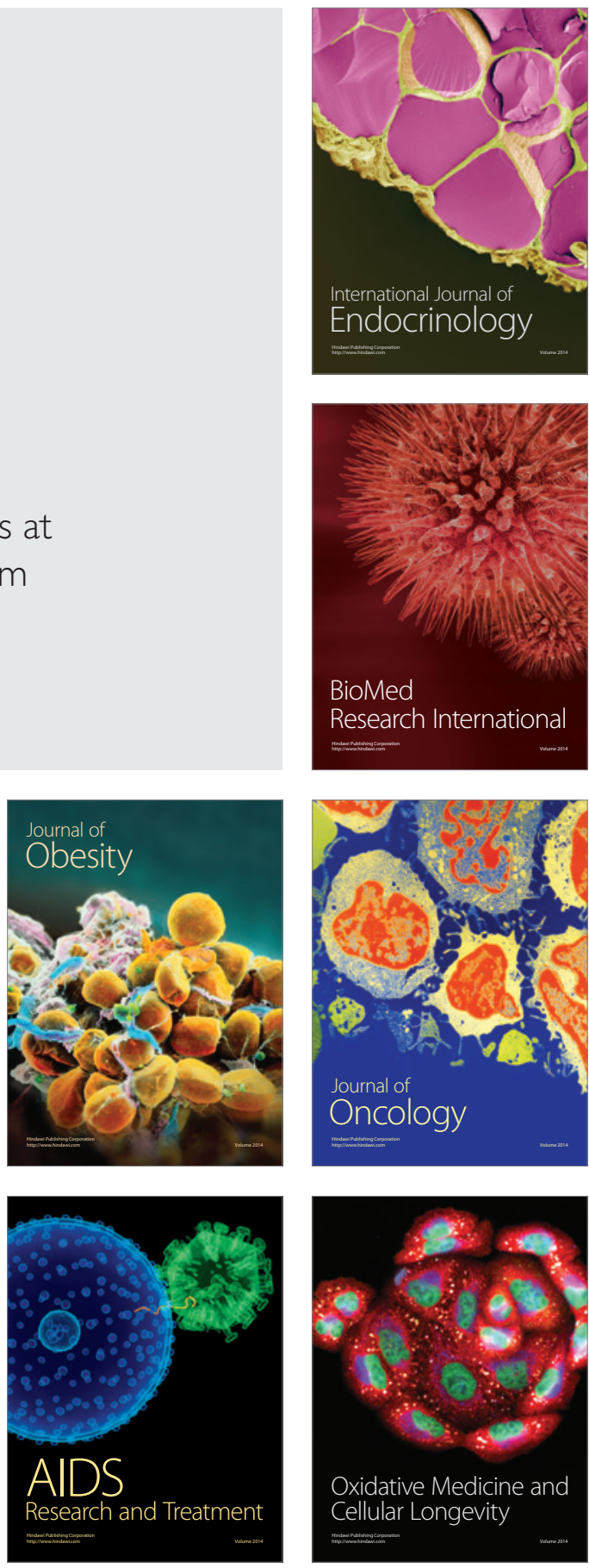